\title{
Article
}

\section{The Town-Plan as Built Heritage}

\section{Vítor Oliveira}

check for updates

Citation: Oliveira, V. The Town-Plan as Built Heritage. Heritage 2021, 4 , 1049-1061. https://doi.org/10.3390/ heritage 4030058

Academic Editor: Éva Lovra

Received: 15 May 2021

Accepted: 21 June 2021

Published: 23 June 2021

Publisher's Note: MDPI stays neutral with regard to jurisdictional claims in published maps and institutional affiliations.

Copyright: (C) 2021 by the author. Licensee MDPI, Basel, Switzerland. This article is an open access article distributed under the terms and conditions of the Creative Commons Attribution (CC BY) license (https:/ / creativecommons.org/licenses/by/ $4.0 /)$.
CITTA Research Centre for Territory Transports and Environment, Rua Roberto Frias s/n, 4200-465 Porto, Portugal; vitorm@fe.up.pt

\begin{abstract}
The physical form of cities is exposed to conflicting forces of change and conservation. In the conservation field, despite the advances achieved over the last decades changing the paradigm from historical monuments to urban landscapes, the focus tends to be on the building fabric and the main three-dimensional characteristics of buildings. This paper proposes a complementary emphasis for conservation - the town-plan, meaning the different patterns of combination of streets, plots, and block-plans of buildings (building footprints). Preserving the town-plan of urban areas built in the past, means bringing to the present significant parts of urban history, assuring diversity (a key characteristic for sustainable, resilient, and safe cities), and providing a basis for the design of new areas more accessible, dense, and continuous. This argument is illustrated in the Chelsea district in New York at two different scales.
\end{abstract}

Keywords: conservation; heritage; urban morphology; urban form; town-plan; streets; plots; blockplans of buildings; New York

\section{Introduction}

Cities are amazing places. Since Humankind started living in cities (the word is used in a wide sense), almost 6000 years ago, these have always been at the centre of evolution [1-3]. From Ur to Rome, from Constantinople (Istanbul) to Baghdad and Chang'an, and from these to London, New York, or Tokyo, the history of cities is, indeed, the history of Humankind. Over this long period, cities have been places of learning, places where men and women have addressed and overcome major challenges and problems that were sometimes raised by the very fact of living and working together in increasingly larger settlements. In the past, present, and future, cities seem to offer the most efficient stage for social interaction and economic development, fostering the creation of enterprises and jobs. It is also expected that cities can lead the way in addressing the fundamental environmental challenges of our time.

Cities are made of people. They are made of men and women, families, people of different ages, individuals living at shorter or longer distances, people of different races, religions, and sexual orientations, and citizens with different educational backgrounds. This intricate social fabric is matched by a complex economic tissue made of different companies and workers. However, cities are also physical constructions. They are made of streets and infrastructures, squares, gardens, and parks, street blocks, plots, special buildings (mostly institutional), and ordinary buildings (mainly residential), to name the most important [4]. While acknowledging the crucial importance of the social, economic, and environmental dimensions of cities, the paper focuses on their physical form.

The physical form of a city is a complex process in time, gathering the action of many different agents, many times with conflicting views [5]. In different parts of the city, from the historical kernel to the peripheral areas, urban form results from the overlap of distinct layers created by different societies and economies in various periods of time. If it is acknowledged that for humankind to have a future, it should have a past and a memory [6], it might be expected that a culture of respect for this built heritage would be developed and even institutionalized. However, cities are in constant transformation, which raises a major 
challenge: under this cultural umbrella, what is to be conserved (in these inherited urban landscapes) and what is to be changed $[7,8]$ ? It is important to consider that conservation should not be exclusive of historical areas and transformation must not be limited to peripheral areas. On the contrary, the tension between conservation and transformation is present in each part of the city. Historical areas must admit selective transformation and peripheral zones should maintain certain elements of urban form. It is also important to bear in mind that the debate on urban form should not be closed. This means that form is important not only because of itself (including built heritage or architectural quality issues) but because of its relationships with other fundamental aspects of cities [9]. Indeed, as societies and economies are the main drivers in shaping the physical form of cities, it might be expected that the later has an influence on the first.

Urban conservation is an idea of modern times, developed after the French Revolution. Over the nineteenth and twentieth centuries, with variations in different geographical contexts, historic monuments were the focus of conservation. While promoting the preservation of these special buildings, this conservation approach allowed, and in some cases supported, the destruction of significant parts of urban landscapes based, for instance, on health, security, and aesthetic considerations. Whilst we can go back to the famous action of Haussmann in Paris in the mid-nineteenth century, this approach can also be found in Moses's intervention in New York one century later. In parallel to this dominant approach, new perspectives on conservation emphasizing the role of the urban landscape started to emerge in the early twentieth century, inspired by works of Sitte, Geddes, and Giovannoni [10-12]. In the 1960s and 1970s, there were important advances, including the preparation of the Venice Charter, the creation of the International Council on Monuments and Sites/ICOMOS (and the subsequent realization of the 'Convention concerning the protection of world cultural and natural heritage' and establishment of the 'World Heritage List') and the making of the first planning documents centred on conservation-notably, the Bologna plan coordinated by Cervelatti. Present debate on urban conservation includes the tension between narrow architectural perspectives (including facadism and pastiche) and a comprehensive understanding of heritage (such as the historic urban landscape approach [13]), the synergies and tensions with planning [14], the importance of cultural tourism in the economy and the pressure of tourists [15], and the contradiction between places that were areas of production in the past and are centres of consumption in the present, to name some of the most important. Debate also reflects the specificities of different geographical and cultural contexts, from China [16] to the United States [17,18]. In the US, historic preservation activities related to the main street and downtown development, promoted by the National Trust for Historic Preservation since the late 1970s, are of particular interest. The way how communities have been implementing this perspective, including four main issues - organization, promotion, design, and economic restructuring has been explored in literature [19]. This focus on the main street can also be framed by research on streetscapes, encompassing different characteristics of urban form, land use, ownership, social capital, local identity and belonging, to name just a few [20-22].

While the usual focus of conservation trends is the building fabric (the three-dimensional characteristics of buildings), this paper proposes a distinct emphasis- the town-plan, meaning the different patterns of combination of streets, plots, and block-plans of buildings. Preserving the town-plan of urban areas that were built in the past means bringing to the present and future some key characteristics that can contribute to make our cities more inclusive, safe, resilient, and sustainable. When considering the preservation of the street system, in opposition to individual buildings or spaces, Karimi argues for the conservation of the 'spatial spirit' of the place [23]. Reproducing this town-plan (and not the building fabric) in the design of new areas would offer the ground for constructing more accessible, dense, diverse, and continuous urban landscapes. The next section offers a review of how the town-plan has been addressed in literature over the last decades, paying particular attention to the historico-geographical approach in urban morphology. Against this background the paper proposes the use of the town-plan as a unifying element-between the past, present, 
and future - that should be preserved. This proposal is explored in the Chelsea district, New York. The application into this case study offers the stage for a wider debate, making evident the contribution of this paper to heritage conservation.

\section{The Town-Plan}

The notable study on Alnwick, Northumberland, developed by German geographer M. R. G. Conzen, is probably the first utilization of the town-plan as it is considered in this paper. Conzen has defined the town-plan as the topographical arrangement of an urban built-up area in all its human-made features. The town-plan contains three distinct complexes of plan elements: (i) streets and their arrangement in a street system; (ii) plots and their aggregation into street blocks; and (iii) buildings or, more precisely, their blockplans (building footprints). Together, the town-plan, the building fabric (three-dimensional characteristics), and the land and building utilization constitute the tripartite division of the urban landscape [24].

Over the last decades both the concept and the method of town-plan analysis have been widely used to describe and explain the physical form of cities. Conzen M. P. offers a remarkable synthesis of the concept and method [25]. Researchers working under the historico-geographical approach [26,27], when addressing the complex processes of urban development, have frequently associated the town-plan framework with other concepts, notably the fringe belt $[28,29]$ and the morphological region $[30,31]$.

In the Alnwick study, Conzen defines the fringe-belt as a belt-like zone originating from the temporarily stationary or slowly advancing fringe of a town and composed of a characteristic mixture of land use units initially seeking peripheral location. Conzen $\mathrm{M}$. R. G. takes the concept proposed by Louis giving it an important role in his morphological theory [32]. Since the late 1960s, Whitehand has progressively extended the scope of the concept, exploring new aspects of its spatial dimension-from city to conurbation, from static to dynamic [33] — adding it an economic [34], an agency, and a planning perspective [35], and confirming its validity in different geographical contexts. The detailed understanding of fringe-belt formation and modification and the economic perspective has been subsequently taken up by Barke [36,37].

A morphological region is an area that has unity in respect of its form that distinguishes it from surrounding areas, based on a combination of town-plan, building fabric, and land and building utilization. The concept of plan unit, considering only the town-plan, was first applied by Conzen in Alnwick. The concept of morphological region would be then developed in Ludlow, where Conzen considers not only the town-plan but the three form complexes. Additionally, he offers a first systematization of the method [38,39]. The purpose of making the method more explicit was developed by Baker and Slater, Barrett, and Bienstman [40-42]. It is also important to mention the first applications of the concept and method into planning practice, particularly in the production of a zoning map and its regulations in Mennecy and Barnt Green [43,44].

Considering the three elements constituting the town-plan, streets (and all other parts of the system of public space) have a higher permanence in time, as they represent the most significant economic effort of a society in the process of city-building. The layout of streets can last for centuries, even surviving natural catastrophes and human-made disasters. Streets support the different flows of a city, allowing access to the different plots, buildings, and activities of the urban system. Shape, length, and width are important characteristics of each street. Yet, research shows that the main variations of the street system are justified by variations in its density, or more specifically, in the density of its nodes and segments [45]. Considering nodes implies considering access to other segments. In this sense, each street would be important by itself and by its relationships with other streets, both in the immediate surroundings and in the whole urban system [46-48]. More specifically, two areas with distinct density in terms of streets nodes and segments at a neighbourhood scale or with distinct accessibility at a city scale would have different potentials of flows. The most expressive differences between different areas seem to be 
related to the time of their construction. When studying Portuguese cities, Monteiro and Pinho, and Oliveira et al. found that the density of street nodes and segments and of street blocks is higher in areas of the city built until the mid-twentieth century than in those built after that date $[49,50]$. This means that, in general, streets and street-blocks created after the mid-twentieth century are less connected (to the neighbourhood and to the whole system) and larger, respectively, than those created before the mid-twentieth century. On the other hand, the analysis of the other part of the timeframe (the older part), reveals three situations. Before the nineteenth century, streets had a high connectivity, balancing the presence of three-way and four-way nodes ( $X$ and $T$ nodes), and street-blocks were small. In the nineteenth century, streets had a high connectivity. They have become more regular and their length and width have increased, enabling connectivity with streets in a wider metric range (three-way nodes have decreased, while four-way nodes have increased). The size of street blocks has slightly increased. In the first half of the twentieth century, street length and the size of street blocks has decreased. Due to the decrease in street length, the relation of each street with streets in a wider range has also decreased.

In general, the second of the three town-plan elements with higher permanence in time is the plot. The intensity of transformation-amalgamation or subdivision processes - depends on the dynamics of change, and the social and economic needs and aspirations of the city and neighborhood. Plots represent the structure of property, the land division and distinction between public and private, and the division between different private owners. The higher the number of plots in a street-block, the greater the possibility of having a higher number of owners and, as such, of getting different strategies for the development of that part of the city. Marcus calls it spatial capital [51]. When considering plots, although size and shape matter, perhaps the most important characteristic is the frontage width. Again, looking at urban form evolution in Portugal, in general, the density of plots was high in medieval times and in the nineteenth century, but then it started progressively decreasing over the twentieth century. This means that, in general, urban landscapes created in the last decades have less plots per street block and, as such, have potentially less agents and urban strategies. Bobkova et al. and Fleischmann et al. are two examples of on-going lines of quantitative research on plots, using large datasets and, in the second case, a high degree of simplification [52,53].

The third element of the town-plan is the block-plans of buildings. Two important aspects when considering this element are density and position. The density of buildings is intimately related to the density of plots. Today, in many countries, the position of each building within the plot is frequently defined by plan regulations. As such, setbacks can be discouraged or promoted by planning. The position of building expresses the relationship between interior and exterior space (building coverage). Certain positions are more effective that others in terms of space organization. More important, this position translates a specific relation between building and street. One of the major changes that has occurred in the urban landscape in the twentieth century was the setback of buildings. While in most buildings erected until the end of the nineteenth century the facade was coincident with plot frontage, in areas developed in the twentieth century, building and plot frontages started to be non-coincident [54]. While setbacks have been originally developed to protect health, offering light and air to buildings and its residents, they have helped greatly to destroy the street as a social space $[55,56]$. Taking the building facade from the plot frontage to an interior position means removing the doors and windows of the building from the plot frontage, transforming the action of walking in the street into a less desirable experience, as many elements of interest are removed.

What is the heritage value of the town-plan? For thousands of years humankind has been living in cities. It has been a long process, involving some ruptures but mainly a continuous improvement of urban forms towards the effective adaptation to human needs. It is remarkable how the main elements of urban form and fundamental patterns of combination that have structured the first cities of Mesopotamia were the same as those of late-nineteenth century, including the major cities of London and New York. Then 
something happened which started to radically transform the dominant processes of city building. Due to a combination of different drivers, including demographic increase, real estate emergence, new patterns of mobility, and new planning theories (mainly the gardencity and the modernist models), some elements of urban form (mainly streets and plots) lost their importance, in theory and in practice, and new urban landscapes started to emerge. These were, and still are, landscapes of low accessibility, density, diversity, and continuity. While acknowledging a few positive aspects in twentieth century processes of city building, this paper argues for a recovery of the structural elements of this six-millennium legacy that were lost in the twentieth century. The preservation of town-plans created before this major rupture of the early twentieth century, as well as the re-creation of these town-plans (controlling streets, plots, and the block-plans of buildings) in the design of new urban areas, while allowing more flexibility in the three-dimensional characteristics of buildings and land uses can contribute to make cities more accessible, dense, diverse, and continuous.

\section{Chelsea, New York}

The last section has reviewed the advances in the town-plan concept. The goal of this paper is to extend this concept, proposing it as unifying framework that must be preserved, and that can bring together the past, present, and future of cities. To illustrate this perspective, the paper focuses on a small area in Chelsea, New York: the street blocks set between the 19th and 24th streets, and the 8th and 10th avenues. These ten street blocks are in the south part of Manhattan Community District 4 (MCD4) - Chelsea, Clinton, and Hudson Yards. MCD4 had 103,000 residents in 2010, meaning an increase of almost 20\% since 2000 (Table 1). Of these 103,000 residents, $52.4 \%$ are male and $47.6 \%$ are female; $30 \%$ of residents are foreign-born; $59 \%$ of residents are White, $17 \%$ are Asian, $16 \%$ are Hispanic, and $5 \%$ are Black. Eight percent of residents are under the age of 18, and 13\% are age 65 and over. There is a strong presence of the LGBTQI+ community. Educational attainment is significantly higher in this district than in Manhattan and New York City. Unemployment and the so-called poverty measure are also higher. Finally, the rent burden and the mean commute to work are more reduced in MCD4.

Table 1. Indicators for MCD4, Manhattan and New York City.

\begin{tabular}{cccc}
\hline & MCD4 & Manhattan & New York City \\
\hline Population, 2010 & 103,245 & $1,585,873$ & $8,175,133$ \\
Population increase, 2000-2010 (\%) & 18 & 3 & 2 \\
Educational attainment (\%) & 74 & 61 & 37 \\
(>25 y with, at least, a bachelor's degree) & 3.7 & 4.2 & 4.9 \\
Unemployment (\%) & 11 & 14 & 20 \\
NYC gov. Poverty measure (\%) & 37 & 45 \\
(residents with incomes below poverty threshold) \\
$\begin{array}{c}\text { Rent burden (\%) } \\
\text { (households spend > 35\% of income on rent) } \\
\text { Mean commute to work (minutes) }\end{array}$ & 27 & 32 & 41 \\
\hline
\end{tabular}

Figure 1 is a reproduction of the 'Map of property belonging to C. C. Moore at Chelsea' prepared in 1835, presenting the streets, street blocks and plots of this area in the mid1830s. Figure 2 presents the current pattern of streets, streets blocks, and plots of the same area. The town-plan of Chelsea, as of a substantial part of Manhattan, was laid down by New York's 1811 plan, designed by Simeon De Witt, Gouverneur Morris, and John Rutherfurd, assisted by surveyor John Randel. The plan proposed the structure for the future development of the city, designing a street system made of 12 avenues and 155 streets, almost 2000 street blocks, a plot structure for each street block, and basic guidance on building alignments and heights [57]. This is a clear example of a town-plan that must be preserved. Figure 1 maps the ground of Chelsea two decades after the design of the plan. The street system fully conforms to the plan. Avenues are $30 \mathrm{~m}$ width and 
streets are $18 \mathrm{~m}$ width (except for 23rd Street, $30 \mathrm{~m}$ width). Street blocks are $60 \mathrm{~m}$ width and about $240 \mathrm{~m}$ long.

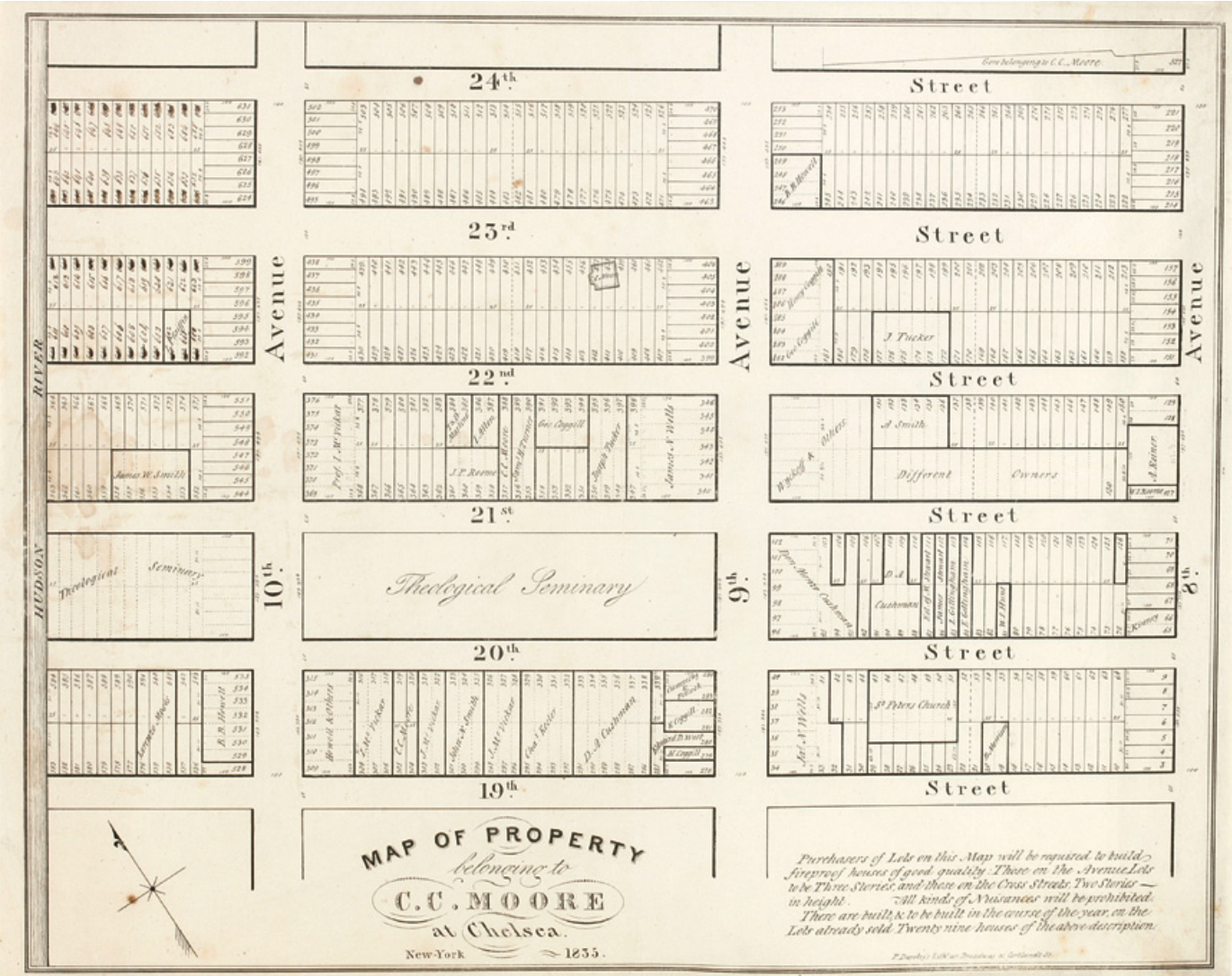

Figure 1. Reproduction of the 'Map of property belonging to C. C. Moore at Chelsea', New York, 1835 (source: public domain).
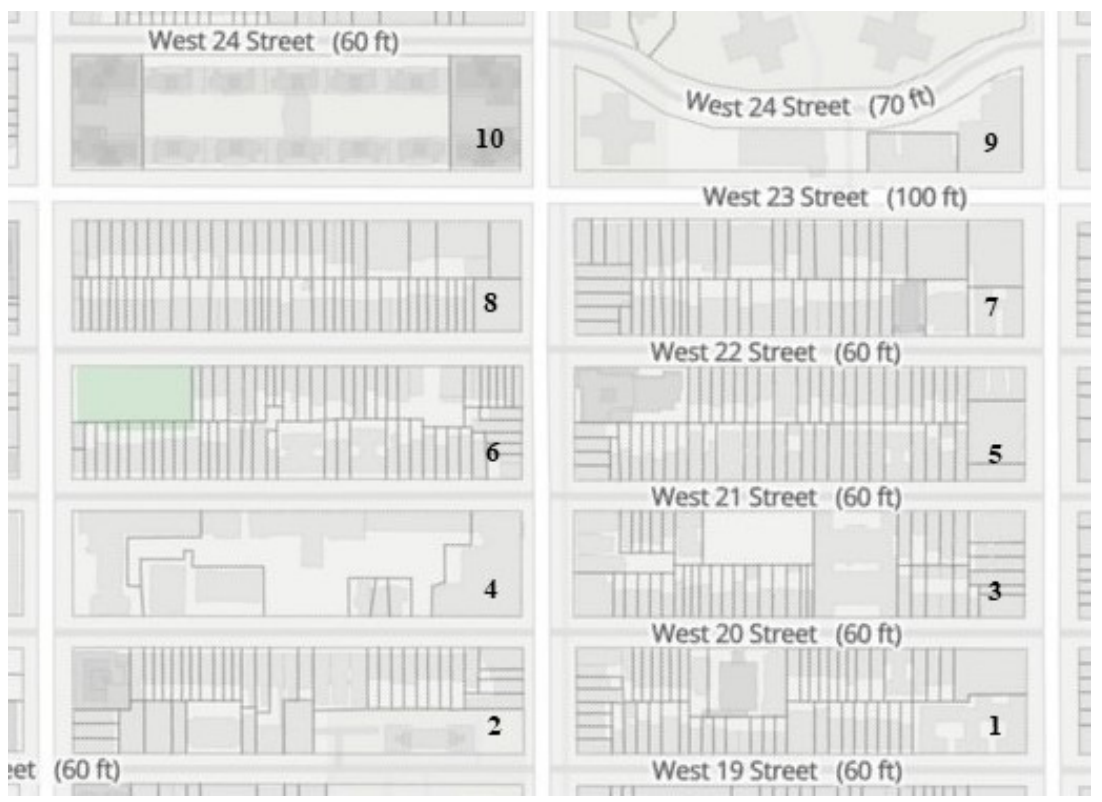

Figure 2. Streets and plots, 2021 (source: New York City's Zoning \& Land Use Map). 
Two of the street blocks (on the top left of the figure-street blocks 8 and 10 in Figure 2) largely conform to the initial layout of the plan, while in the other eight several plots have already been bought by the same agent. Each of these two street blocks is made of 64 plots (16 facing the avenues and 48 facing the streets)-Table 2. Each plot is about $7.5 \mathrm{~m}$ width and $30 \mathrm{~m}$ long. In the other eight blocks, there have been many processes of plot amalgamation-from two plots to a whole street block (street block 4, owned by the Theological Seminar). Street block 2 is a good example of the flexibility of the grid and of how different agents have developed different ownership strategies. In the mid-1830s, the street block was made of 62 plots. Twelve agents owned 60 of these plots (one of the agents had 12 plots), while two of the plots were not sold yet. These 10 street blocks included 561 plots. In the bottom of the 1835 map, it is written that the avenue's plots would have three-story houses and the streets' plots would have two-story houses.

Table 2. Town-plan evolution in ten street blocks, Chelsea (1835-2021).

\begin{tabular}{cccc}
\hline & $\mathbf{1 8 3 5}$ & & $\mathbf{2 0 2 1}$ \\
\cline { 2 - 4 } & Plots & Plots & Buildings \\
\hline Street block 1 & 62 & 52 & 56 \\
Street block 2 & 62 & 40 & 44 \\
Street block 3 & 62 & 45 & 48 \\
Street block 4 & 1 & 7 & 10 \\
Street block 5 & 60 & 55 & 55 \\
Street block 6 & 59 & 61 & 64 \\
Street block 7 & 63 & 48 & 50 \\
Street block 8 & 64 & 62 & 67 \\
Street block 9 & 64 & 2 & 4 \\
Street block 10 & 64 & 3 & 16 \\
Total & 561 & 375 & 414 \\
\hline
\end{tabular}

The implementation of the street system proposed by the 1811 plan was a long process - it took about 60 years for the grid to be built up to 155th Street. The process included some changes: (i) the maintenance of Broadway; (ii) the construction of two new avenues (Lexington and Madison); (iii) the creation of new open spaces-neighbourhood parks and squares (from Union Square to Bryant Park) in a first stage and Central Park in a second stage; (iv) the enlargement of some axes (Park Avenue, Lenon Avenue, Adam Clayton Powell Boulevard, and 17 of the east-west streets). Another important change, in the twentieth century, was the incorporation of 'superblocks' into the grid, erasing some street sections. While some were formed for monumental buildings (New York Public Library, Grand Central Terminal), others contained monumental ensembles (Columbia University, Rockefeller Center, Lincoln Center). From the 1930s through the middle of the century, some sections of the grid were obliterated to create large housing projects. The study area includes one of these changes in the street system-a housing project, between 24th and 28th streets, developed in the early 1960s. While the ten street blocks had 561 plots in 1835, they have 375 plots in 2021 . This represents a loss of $1 / 3$ of plots. Yet, it also reveals how resilient this design of the ground proposed by the plan 200 years ago was, in a city as dynamic as New York, growing from about 100,000 to more than 8,000,000 inhabitants. Remarkably, two of the ten street-blocks have increased the number of plots over the two last centuries. Although the ground of Manhattan has been planned, the narrow and deep plot that characterizes this vast urban area is a key element of urban landscapes, non-planned, of medieval and nineteenth century origin in other parts of the world. These 375 plots include 414 buildings. While in eight street blocks ( 1 to 8 ) the building and plot frontages are mostly coincident, in two street blocks ( 9 and 10) the building and plot frontages are mostly non-coincident.

Figures 3 and 4 , and Tables 3 and 4 focus on street block 6 offering a more detailed view of the case study area. Of the 61 plots in this street block, $85 \%$ have a 4 to $8 \mathrm{~m}$ width, 
and $55 \%$ of the total still falls in the plot width type proposed by the 1811 plan. Clement Clarke Moore Park, plot 33 in the corner of 10th Avenue and 22nd Street, is an exceptionally large plot in the street block, with a $64.7 \mathrm{~m}$ width. Other large plots are plot $51(36.4 \mathrm{~m})$ containing four buildings, and probably resulting from plot amalgamation in the 1960s; and plots $13(25.8 \mathrm{~m})$ and $10(19.8 \mathrm{~m})$ containing the largest block-plans of buildings in the street block, and were most likely subject to plot amalgamation in the 1930s.

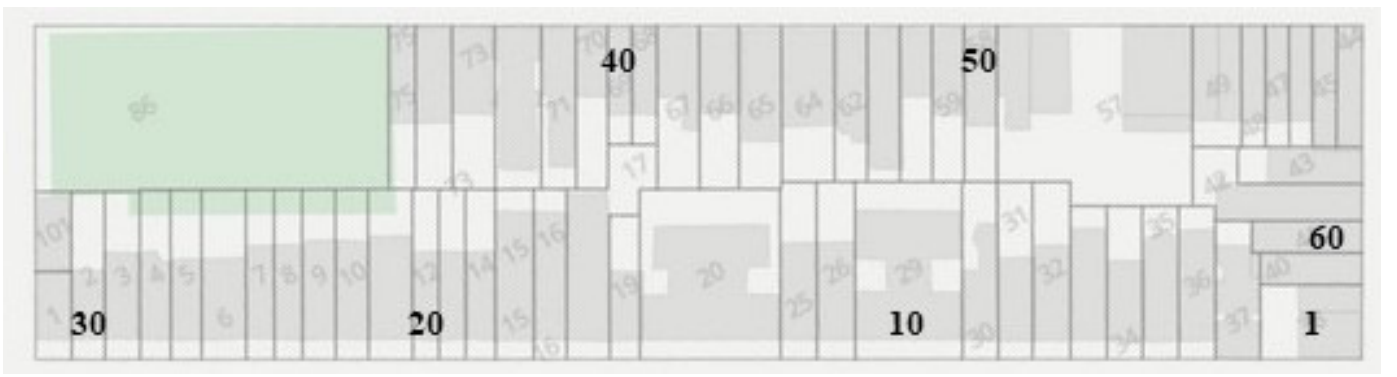

Figure 3. Street block 6, 2021 (source: New York City's Zoning \& Land Use Map).

Table 3. Street block 6, 21st Street and 10th Avenue (source: New York City's Zoning \& Land Use Map).

\begin{tabular}{|c|c|c|c|c|c|c|}
\hline \multirow{2}{*}{$\begin{array}{c}\text { Plot } \\
\text { Number and } \\
\text { Location }\end{array}$} & \multicolumn{2}{|c|}{ Plot } & \multicolumn{2}{|l|}{ Building } & \multirow[b]{2}{*}{ Utilization } & \multirow[b]{2}{*}{ Owner } \\
\hline & $\begin{array}{l}\text { Area } \\
\left(\mathrm{m}^{2}\right)\end{array}$ & $\begin{array}{l}\text { Frontage } \\
\text { (m) }\end{array}$ & $\begin{array}{c}\text { Year } \\
\text { Original, Alteration }\end{array}$ & Floors & & \\
\hline 1-Corner & 810.7 & 13.5 & 1910 & 2 & MRC (1) & J. Steven Shore \\
\hline $2-21$ st St & 640.0 & 8.2 & 1889 & 5 & RMF-10 & - \\
\hline $3-21$ st St & 603.5 & 6.7 & $1853(1976)$ & 4 & RMF-12 & - \\
\hline $4-21$ st St & 603.5 & 6.7 & 1853 & 4 & RSF & Lubica Mason \\
\hline $5-21$ st St & 603.5 & 6.7 & $1853(1962)$ & 5 & RMF-5 & Chelsea Square North Inc \\
\hline $6-21 s t$ St & 603.5 & 6.7 & $1853(1962,2009)$ & 5 & $\mathrm{RMF}-5$ & Chelsea Square North Inc \\
\hline $7-21$ st St & 700.7 & 6.7 & $1843(1983,2008)$ & 4 & RSF & Maryam Banikarim \\
\hline $8-21$ st St & 700.7 & 6.7 & $1843(2000,2006)$ & 3 & RSF & The J. R. Walsh R. Trust \\
\hline $9-21$ st St & 700.7 & 6.7 & $1843(1993,2017)$ & 3 & $\mathrm{RMF}-3$ & Samuel M. Bisbee \\
\hline $10-21$ st St & 2057.4 & 19.8 & $1938(1989)$ & 6 & $\mathrm{RMF}-36$ & 421 West 21st Street LLC \\
\hline $11-21$ st St & 697.3 & 6.7 & $1853(2009)$ & 6 & $\mathrm{RMF}-5$ & George Fares \\
\hline $12-21 s t$ St & 716.2 & 6.9 & $1853(2016)$ & 4 & $\mathrm{RMF}-5$ & 427 W21 St CP \\
\hline $13-21 s t$ St & 2554.5 & 25.8 & $1930(1988)$ & 13 & RMF-69 & 433 West Associates \\
\hline $14-21$ st St & 480.6 & 5.7 & 1853 (2009) & 4 & $\mathrm{RMF}-8$ & High Line 21 Corporation \\
\hline $15-21 s t S t$ & 1089.6 & 7.6 & $1854(1999,2006)$ & 5 & $\mathrm{RMF}-3$ & E Griswold Morgan \\
\hline $16-21$ st St & 594.3 & 6.0 & $1854(1999)$ & 3 & RSF & Mack Joshua L \\
\hline $17-21$ st St & 772.3 & 7.8 & 1898 & 5 & RMF-10 & Jundi Hada \\
\hline $18-21$ st St & 501.7 & 5.0 & 1857 (1999) & 4 & RSF & P. John Murrin \\
\hline $19-21 s t$ St & 501.7 & 5.0 & $1857(1982,2013)$ & 5 & RSF & E F Baker Tobin \\
\hline $20-21$ st St & 501.7 & 5.0 & 1857 & 4 & RSF & DGT Chelsea Holdings LLC \\
\hline $21-21$ st St & 753.4 & 7.6 & $1853(1954)$ & 4 & RMF-5 & 453W 21St LLC \\
\hline $22-21 s t S t$ & 601.9 & 6.0 & 1854 & 4 & $\mathrm{RMF}-4$ & C A Pallange Howell \\
\hline $23-21 s t S t$ & 601.9 & 6.0 & 1854 & 5 & RMF-10 & The George C Cabell \\
\hline $24-21$ st St & 526.6 & 5.3 & $1854(1964,1999)$ & 4 & RSF & John K L Bortwick \\
\hline $25-21$ st St & 526.6 & 5.3 & $1854(1963)$ & 4 & $\mathrm{RMF}-4$ & Jackalope East LLC \\
\hline $26-21 s t$ St & 752.2 & 7.6 & $1836(1972)$ & 4 & $\mathrm{RMF}-6$ & 463 West 21St INC \\
\hline $27-21$ st St & 601.9 & 6.0 & 1853 & 3 & RTF & 29 Chelsea Square North LP \\
\hline $28-21$ st St & 601.9 & 6.0 & 1853 & 3 & RSF & Anne E Delaney \\
\hline $29-21$ st St & 592.8 & 6.0 & 1853 & 3 & RSF & Chenzhou Family LLC \\
\hline $30-21$ st St & 592.8 & 6.0 & $1853(2000)$ & 3 & RTF & Adam H Seessel \\
\hline 31 - Corner & 322.4 & 6.0 & $1853(1999,2012)$ & 3 & RSF & Robert S Bailin \\
\hline $32-10$ th Av & 269.1 & 6.0 & 1891 & 3 & MRC (1) & 188 Tenth Av Corporation \\
\hline 33-Corner & 6493.1 & 64.7 & - & - & OS & NYC D Parks Recreation \\
\hline
\end{tabular}

Notes: CO—Commercial and Office, MRC—Mixed Residential and Commercial, OS—Open Space, PF—Public Facilities, RMF—Residential Multi-Family, RTF-Residential Two-Family, RSF-Residential Single-Family. 
Table 4. Street block 6, 22nd Street and 9th Avenue (source: New York City's Zoning \& Land Use Map).

\begin{tabular}{|c|c|c|c|c|c|c|}
\hline \multirow{2}{*}{$\begin{array}{c}\text { Plot } \\
\text { Number and } \\
\text { Location }\end{array}$} & \multicolumn{2}{|c|}{ Plot } & \multicolumn{2}{|l|}{ Building } & \multirow[b]{2}{*}{ Utilization } & \multirow[b]{2}{*}{ Owner } \\
\hline & $\begin{array}{l}\text { Area } \\
\left(\mathrm{m}^{2}\right)\end{array}$ & $\begin{array}{l}\text { Frontage } \\
(\mathrm{m})\end{array}$ & $\begin{array}{c}\text { Year } \\
\text { Original, Alteration }\end{array}$ & Floors & & \\
\hline $34-22$ nd St & 481.5 & 4.8 & $1854(1989,2013)$ & 4 & RSF & DRGB y Asociados LLC \\
\hline $35-22$ nd St & 647.0 & 6.5 & 1854 & 4 & $\mathrm{RMF}-5$ & Finn G Isdahl \\
\hline $36-22$ nd St & 750.4 & 7.6 & 1839 & 4 & RMF-15 & 456 W 22nd St Part 1 LLC \\
\hline $37-22$ nd St & 865.3 & 8.7 & 1897 (1987) & 5 & RMF-16 & 456 W 22nd St Part 1 LLC \\
\hline $38-22$ nd St & 639.4 & 6.4 & 1835 & 4 & RMF-15 & Chelsea Equities LLC \\
\hline $39-22$ nd St & 601.9 & 6.0 & 1835 & 2 & RTF & Joanne Downes \\
\hline $40-22$ nd St & 329.1 & 4.5 & $1854(1999,2009)$ & 4 & RTF & David Vence \\
\hline $41-22$ nd St & 329.1 & 4.5 & $1854(2005)$ & 4 & RTF & $446 \mathrm{~W}$ 22nd Street LLC \\
\hline $42-22$ nd St & 752.5 & 7.6 & 1836 & 3 & $\mathrm{RMF}-3$ & $444 \mathrm{~W}$ 22nd Street LLC \\
\hline $43-22$ nd St & 750.4 & 7.6 & 1847 & 4 & $\mathrm{RMF}-24$ & Chelsea 442 LLC \\
\hline $44-22$ nd St & 752.5 & 7.6 & 1836 & 3 & $\mathrm{RMF}-6$ & The Michael Minick LLC \\
\hline $45-22$ nd St & 940.6 & 10.0 & $1900(1984)$ & 3 & RMF-6 & Jeffrey Preston \\
\hline $46-22$ nd St & 567.8 & 6.0 & 1900 & 3 & $\mathrm{RMF}-4$ & Jeffrey Preston \\
\hline $47-22$ nd St & 553.2 & 5.9 & $1843(2000,2017)$ & 3 & $\mathrm{RMF}-3$ & The Weinberg 2011 Trust \\
\hline $48-22$ nd St & 543.7 & 5.8 & $1843(2015)$ & 3 & RTF & Padukone Maitreya \\
\hline $49-22$ nd St & 555.0 & 5.9 & 1843 & 2 & RTF & Carolyn N R Meinhardt \\
\hline $50-22$ nd St & 552.6 & 5.9 & $1843(1984)$ & 3 & $\mathrm{RMF}-3$ & 426 W 22nd Associates LLC \\
\hline $51-22$ nd St & 3723.1 & 36.4 & 1960 & 4 & $\mathrm{RMF}-20$ & 414-424 W 22nd Street LLC \\
\hline $52-22$ nd St & 624.8 & 8.6 & 1856 & 4 & RMF-12 & 410 Holdings, LLC \\
\hline $53-22$ nd St & 312.7 & 4.3 & $1856(1986)$ & 4 & $\operatorname{MRC}(6)$ & Katie D Wong \\
\hline $54-22$ nd St & 312.7 & 4.3 & $1856(1959)$ & 4 & RMF-10 & London Apartments LLC \\
\hline $55-22$ nd St & 312.7 & 4.3 & $1856(1966)$ & 4 & $\mathrm{RMF}-5$ & 404 Manhattan Reality \\
\hline $56-22$ nd St & 312.7 & 4.3 & 1856 & 4 & $\mathrm{RMF}-7$ & Sullkor Reality Chelsea LLC \\
\hline 57-Corner & 312.7 & 4.3 & $1856(1984)$ & 4 & MRC (5) & 400 West 22nd Street \\
\hline $58-9$ th Av & 473.6 & 6.4 & $1858(1964)$ & 5 & PF & Div of Adm Revenue MGT \\
\hline $59-9$ th Av & 835.7 & 7.0 & 1856 & 4 & MRC (4) & Terri Zimmerman \\
\hline $60-9$ th Av & 368.1 & 5.6 & 1868 & 2 & $\mathrm{CO}$ & Langer 189 LLC \\
\hline $61-9$ th Av & 339.8 & 5.6 & 1868 & 2 & $\mathrm{CO}$ & Yamco II, LLC \\
\hline
\end{tabular}

Notes: CO—Commercial and Office, MRC—Mixed Residential and Commercial, OS—Open Space, PF—Public Facilities, RMF—Residential Multi-Family, RTF—Residential Two-Family, RSF—Residential Single-Family.

More than half of the buildings in this street block have been erected in the 1850s. Almost one-fourth of these buildings were built in the 1830s and 1840 s. Only $10 \%$ of the buildings have been erected in the twentieth century. More than half of the building have been altered over the last seven decades, with no significant alterations in the facades. Almost half of the buildings have four stories and one-fourth of them have three stories (one building has 13 stories).

More than half of the buildings are residential and multi-family (most with less than 10 dwellings); $20 \%$ are single-family, and around $10 \%$ are two-family buildings. Almost $10 \%$ are mixed residential and commercial buildings. There are two buildings for commerce and office, one public facility, and one green area.

There is a high diversity of agency in the street block. Only three agents own more than one plot (two plots): 'Chelsea Square North Inc' (plots 5 and 6), '456 W 22nd St Part 1 LLC' (plots 36 and 37), and Jeffrey Preston (45 and 46). The plots and buildings owned by these three agents are not very different- the plot width is 6.0 to $10.0 \mathrm{~m}$, and the building height is three to five stories. The number of dwellings in plots 36 and 37 is the triple of dwellings in the other plots. Ownership data for two of the 61 plots is not available. 

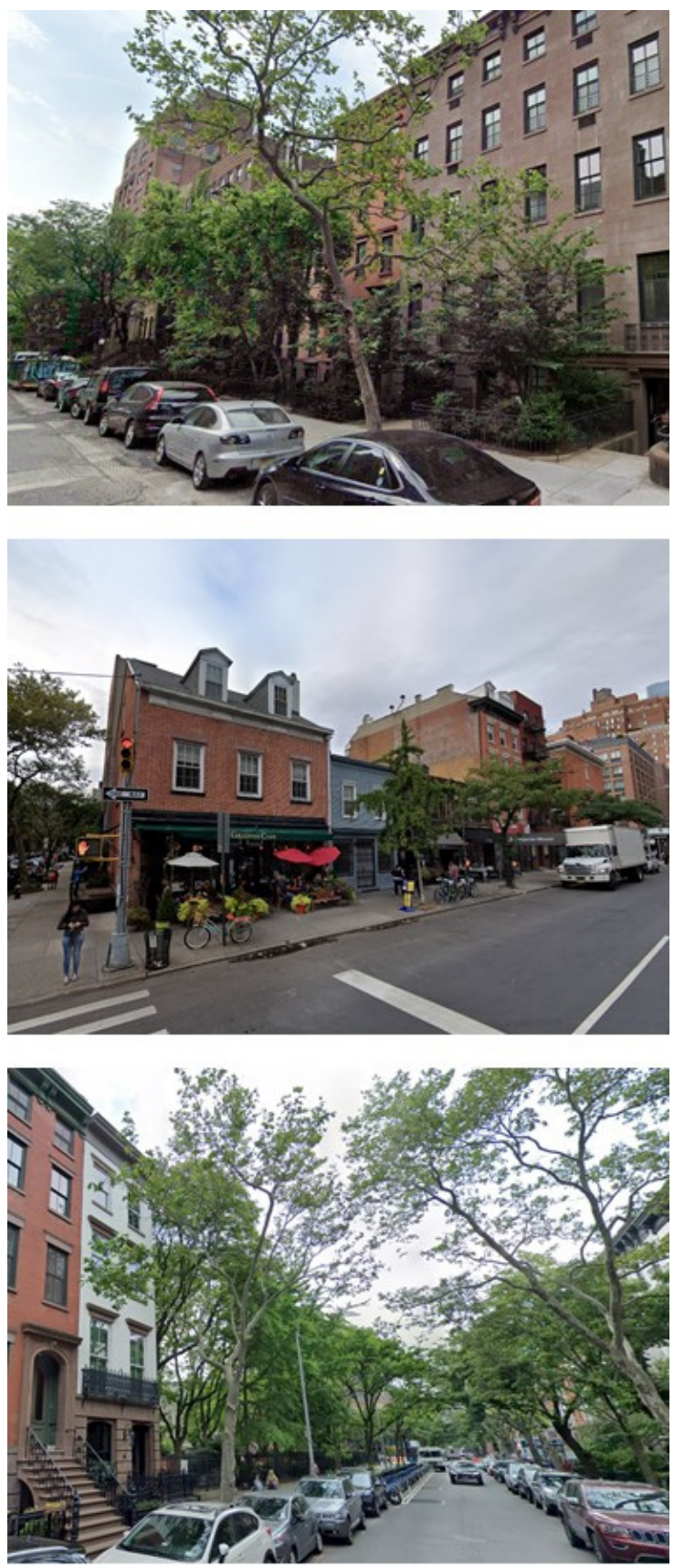

Figure 4. Street block 6: 21st Street looking west (including the 13-story building in plot 13), 9th Avenue facing north, and 22nd Street looking west (Clement Clarke Moore Park in the south corner) (source: Google Maps).

\section{Discussion}

The importance of the town-plan in urban landscape-as a combination of streets, plots, and the block-plans of buildings-has been debated in literature, particularly in urban morphology. This paper argues for its consideration in frameworks of conservation and heritage, together with the building fabric. This is so important as the widening of scope from singular buildings (monuments) to common buildings or built areas (mostly residential) that occurred after the mid-twentieth century.

Manhattan is a notable example of the persistence of a town-plan over time. The orthogonal pattern of streets and avenues, the rectangular street blocks $(60 \mathrm{~m}$ width and variable length, decreasing from centre to the margins of the island), the narrow and long 
plots (6 to $7.5 \mathrm{~m}$ width, $30 \mathrm{~m}$ long), and the general guidance on buildings (position in plots, different heights according to avenues or streets) offered the physical support for two centuries of urban history of one of the two first megacities in the world.

If diversity is acknowledged as a fundamental characteristic of cities, the town-plan can offer a profound contribution for its achievement and development. A town-plan made of accessible streets, small to medium-size street blocks, a high density of plots and a high coincidence of building and plot frontages will contribute for the presence of distinct agents, different utilizations (including several types of residential uses), and different buildings' heights and ages_-and, as such, of residents with different socioeconomic backgrounds. The Chelsea case study clearly illustrates this statement.

Manhattan's town-plan, while being the most stable element of urban form, has been able to accommodate change over the last 210 years. While it does not fit into the scope of this paper, focused on the long-term change, future research should address recent dynamics (such as the High Line project), in order to explore additional elements to reinforce the main argument of the paper. It is argued that analysis of the transformations carried out over the last two centuries can offer guidance for future change and the design of new urban forms. While the 1835 map, prepared two decades after the 1811 plan, already registered different possibilities of plot amalgamation (from two plots only to more than 60 plots constituting street block 4), the different buildings erected in the following decades can illustrate how the town-plan has combined permanence (of the most structural elements) and change (of the most ephemeral elements, such as architectural styles and building heights). Our case study, made of 10 street blocks, offers two interesting examples.

The first is 433 West 21 Street (plot 13, street block 6)-Figures 3 and 4, top. The $26 \mathrm{~m}$-width plot probably results from the amalgamation of four plots. The building, erected in 1930, conserves the dominant alignment (a slight setback from the street) and one of the dominant building materials, bricks. While the architectural style was new in the street, it did establish a careful relation in terms of the facade design. On the contrary, change is clear in building height. It is a 13-story building in a street dominated by fouror three-story buildings. Another important difference is that this building is made of 69 dwellings, while most of the other buildings have less than 10 dwellings.

While the former illustrates the insertion of a large residential building into an extant residential frontage, erected one century earlier, Public School 11 (315 West 20 Street-street block 3; Figure 2) is an example of the construction of an institutional building in the mid-1920s. The plot, also facing 21st Street, probably results from the amalgamation of 12 plots (six in each street). While the peripheral areas of the building are aligned with the surrounding buildings, its central parts setback form the street. Building height fits the surrounding building fabric. As most institutional buildings, the school has a large block-plan-that is the only major change it introduces in this urban landscape.

At the city scale, Columbia University, in Manhattan Community District 9, stands out as another remarkable case of relationship between institutional buildings and the 1811 town-plan (the basic plot metric is for residential buildings). Columbia occupies six street blocks (the major change), between 114th and 120th streets, and 10th and 11th avenues, plus surrounding extensions. The construction of the notable complex of buildings started in 1900. While interrupting some streets, the complex allows the continuation of others as paths within the open space of the institution. Building and plot frontages coincide. All this contributes to establishing a profound physical continuity with the surrounding urban landscape.

Clement Clarke Moore Park is an example of the inclusion of a green area into the corner of a street block (plot 33, street block 6, Figure 3). Throughout the last two centuries, many other examples of green areas, of very different size, that were not in the 1811 plan, have been created in Manhattan-from Bryant Park (part of two street blocks) and Union Square (part of three street blocks) to the Central Park (occupying 153 street blocks). 


\section{Conclusions}

This paper argued for a change of paradigm in conservation debate and policy—giving the town-plan a similar role as the building fabric. Based on recent advances of scientific knowledge on the town-plan, and to some extent on the exploratory case study, the paper offered three main reasons for this change of paradigm. Firstly, preserving the town-plan of an urban area built in the past, as Chelsea, means bringing to the present significant parts of its urban history. Each street and avenue, each plot and each block-plan of building created in these two centuries is part of New York urban history. Secondly, preserving a town-plan created in a period former to the main ruptures introduced in cities over the twentieth century is a contribution to assuring diversity. The detailed analysis of street block 6 made evident the diversity of agents, land and building utilization, and buildings, with a high potential for attracting people with diverse socioeconomic backgrounds. Thirdly, preserving such a town-plan provides the basis for the design of new areas (made of new buildings) more accessible, dense, and continuous, recovering the fundamental strengths of the urban landscapes created before the twentieth century.

Funding: This research was funded by FCT: CEECIND/01311/2017.

Institutional Review Board Statement: Not applicable.

Informed Consent Statement: Not applicable.

Data Availability Statement: Not applicable.

Conflicts of Interest: The author declares no conflict of interest.

\section{References}

1. Morris, A.E.J. History of Urban Form: Before the Industrial Revolution; George Godwin Limited: London, UK, 1972.

2. Schoenauer, N. 6000 Years of Housing; W W Norton and Company: New York, NY, USA, 1981.

3. Cataldi, G. Primitive Dwellings; Aión Edizioni: Florence, Italy, 2015.

4. Oliveira, V. Urban Morphology. In An Introduction to the Study of the Physical form of Cities; Springer: Cham, Switzerland, 2016.

5. Whitehand, J.W.R.; Whitehand, S.M. The study of physical change in town centres: Research procedures and types of change. Trans. Inst. Br. Geogr. 1983, 8, 483-507. [CrossRef]

6. Barke, M. The importance of urban form as an object of study. In Teaching Urban Morphology; Oliveira, V., Ed.; Springer: Cham, Switzerland, 2018; pp. 11-30.

7. Larkham, P.J. Conservation and the City; Routledge: London, UK, 1996.

8. Orbasli, A. Tourists in Historic Towns: Urban Conservation and Heritage Management; E \& FN Spon: London, UK, 2002.

9. Talen, E.; Wheeler, S.; Anselin, L. The social context of U. S. built landscapes. Landsc. Urban Plan. 2018, 177, 266-280. [CrossRef]

10. Sitte, C. Der Stadetbau nach Seinen Kunstlerischen Grüdsätzen; Birkhäuser: Basel, Switzerland, 1889.

11. Geddes, P. Cities in Evolution; Harper \& Row: New York, NY, USA, 1915.

12. Giovannoni, G. Vecchie Cittá ed Edilizia Nova; Unione Tipografico-Editrice Torinese: Turin, Italy, 1931.

13. Bandarin, F.; Van Oers, R. The Historic Urban Landscape: Managing Heritage in an Urban Century; Wiley-Blackwell: Chichester, UK, 2012.

14. Minner, J. Revealing synergies, tensions, and silences between preservation and planning. J. Am. Plan. Assoc. 2016, 82, 72-87. [CrossRef]

15. Nasser, N. Planning for urban heritage places: Reconciling conservation, tourism, and sustainable development. J. Plan. Lit. 2003, 17, 467-479. [CrossRef]

16. Whitehand, J.W.R.; Gu, K.; Whitehand, S.M.; Zhang, J. Urban morphology and conservation in China. Cities 2011, 28, 171-185. [CrossRef]

17. Tyler, N.; Tyler, I.; Ligibel, T. Historic Preservation: An Introduction to Its History, Principles, and Practice; W. W. Norton \& Company: New York, NY, USA, 1994.

18. Frank, K.; Petersen, P. (Eds.) Historic Preservation in the USA; Springer: Cham, Switzerland, 2002.

19. Robertson, K. The main street approach to downtown development: An examination of the four-point program. J. Archit. Plan. Res. 2004, 1, 55-73.

20. Litvin, S. Streetscape improvements in an historic tourist city a second visit to King Street, Charleston, South Carolina. Tour. Manag. 2005, 26, 421-429. [CrossRef]

21. Zukin, S. The social production of urban cultural heritage: Identity and ecosystem on an Amsterdam shopping street. City Cult. Soc. 2012, 3, 281-291. [CrossRef]

22. Vaughan, L. (Ed.) Suburban Urbanities: Suburbs and the Life of the High Street; UCL Press: London, UK, 2015. 
23. Karimi, K. Urban conservation and spatial transformation: Preserving the fragments or maintain the 'spatial spirit'. Urban Des. Int. 2000, 5, 221-231. [CrossRef]

24. Conzen, M.R.G. Alnwick Northumberland: A Study in Town-Plan Analysis; Institute of British Geographers Publication 27; George Philip: London, UK, 1960.

25. Conzen, M.P. Core concepts in town-plan analysis. In Teaching Urban Morphology; Oliveira, V., Ed.; Springer: Cham, Switzerland, 2018; pp. 122-143.

26. Whitehand, J.W.R. (Ed.) The Urban Landscape: Historical Development and Management; Papers by MRG Conzen; Academic Press: London, UK, 1981.

27. Oliveira, V. (Ed.) JWR Whitehand and the Historico-Geographical Approach to Urban Morphology; Springer: Cham, Switzerland, 2019.

28. Conzen, M.P. How cities internalize their former urban fringes: A cross-cultural comparison. Urban Morphol. 2009, 13, 29-54.

29. Ünlü, T. Thinking about urban fringe belts: A Mediterranean perspective. Urban Morphol. 2013, 17, 5-20.

30. Whitehand, J.W.R. The structure of urban landscapes: Strengthening research and practice. Urban Morphol. 2009, $13,5-27$.

31. Oliveira, V.; Yaygin, M. The concept of the morphological region: Developments and prospects. Urban Morphol. $2020,24,35-52$.

32. Louis, H. Die Geographische Gliederung Von Gross-Berlin; Stuttgart: Engelhorn, Germany, 1936; pp. $146-171$.

33. Whitehand, J.W.R. Fringe belts: A neglected aspect of urban geography. Trans. Inst. Br. Geogr. 1967, 41, 223-233. [CrossRef]

34. Whitehand, J.W.R. Building cycles and the spatial pattern of urban growth. Trans. Inst. Br. Geogr. 1972, 56, 39-55. [CrossRef]

35. Whitehand, J.W.R.; Morton, N.J. Urban morphology and planning: The case of fringe belts. Cities 2004, 21, 275-289. [CrossRef]

36. Barke, M. The changing urban fringe of Falkirk: Some morphological implications of urban growth. Scott. Geogr. Mag. 1974, 90, 85-97. [CrossRef]

37. Barke, M. Morphogenesis, fringe belts and urban size: An exploratory essay. In The Built Form of Western Cities; Slater, T.R., Ed.; Leicester University Press: Leicester, UK, 1990; pp. 279-299.

38. Conzen, M.R.G. Geography and townscape conservation. In Giessener Geographische Schriften; Uhlig, H., Lienau, C., Eds.; Anglo-German Symposium in Applied Geography Giessen-Würzburg-München: Giessen, Germany, 1973 ; pp. 95-102.

39. Conzen, M.R.G. Morphogenesis, morphological regions and secular human agency in the historic townscape. In Urban Historical Geography; Denecke, D., Shaw, G., Eds.; Cambridge University Press: Cambridge, UK, 1988; pp. 253-272.

40. Baker, N.J.; Slater, T.R. Morphological regions in English medieval towns. In Urban Landscapes: International Perspectives; Whitehand, J.W.R., Larkham, P.J., Eds.; Routledge: London, UK, 1992; pp. 43-68.

41. Barrett, H.J. Townscape Changes and Local Planning Management in City Conservation Areas: The Example of Birmingham and Bristol. Ph.D. Thesis, University of Birmingham, Birmingham, UK, 1996. Unpublished.

42. Bienstman, H. Morphological Concepts and Urban Landscape Management. Ph.D. Thesis, University of Birmingham, Birmingham, UK, 2007. Unpublished.

43. Kropf, K.S. An alternative approach to zoning in France: Typology, historical character and development control. Eur. Plan. Stud. 1996, 4, 717-737. [CrossRef]

44. Whitehand, J.W.R. Conzenian research in practice. In Morphological Research in Planning, Urban Design and Architecture; Oliveira, V., Ed.; Springer: Cham, Switzerland, 2021; pp. 19-42.

45. Remali, A.M.; Porta, S. Street networks and street-blocks in the city centre of Tripoli. Urban Morphol. 2017, 21, 161-179.

46. Hillier, B.; Hanson, J. The Social Logic of Space; Cambridge University Press: Cambridge, UK, 1984.

47. Hillier, B. Space is the Machine; Cambridge University Press: Cambridge, UK, 1996.

48. Marshall, S.; Gil, J.; Kropf, K.; Tomko, M.; Figueirdo, L. Street network studies. Netw. Spat. Econ. 2018, 18, 735-749. [CrossRef]

49. Monteiro, A.C.; Pinho, P. MAP, a methodology for Morphological Analysis and Prescription. Urban Morphol. $2021,25,57-75$.

50. Oliveira, V.; Medeiros, V.; Corgo, J. The urban form of Portuguese cities. Urban Morphol. 2020, 24, 145-166.

51. Marcus, L. Spatial capital. J. Space Syntax 2010, 1, 30-40.

52. Bobkova, E.; Marcus, L.; Berghauser Pont, M.; Stavroulaki, I.; Bolin, D. Structure of plot systems and economic activity in cities. Urban Sci. 2019, 3, 66. [CrossRef]

53. Fleischmann, M.; Feliciotti, A.; Romice, O.; Porta, S. Morphological tessellation as a way of partitioning space. Comput. Environ. Urban Syst. 2020, 80, 101441. [CrossRef]

54. Dibble, J.; Prelorendjos, A.; Romice, O.; Zanella, M.; Strano, E.; Pagel, M.; Porta, S. On the origins of spaces: Morphometric foundations of urban form evolution. Environ. Plan. B 2019, 46, 707-730. [CrossRef]

55. Alexander, C.; Ishikawa, S.; Silverstein, M.; Jacobson, M.; Fiksdahl-King, I.; Angel, S. A Pattern Language; Oxford University Press: New York, NY, USA, 1977.

56. Marshall, S. Streets \& Patterns; Spon Press: London, UK, 2005.

57. Ballon, H. (Ed.) The Greatest Grid: The Master Plan of Manhattan 1811-2011; Museum of the City of New York and Columbia University Press: New York, NY, USA, 2012. 